\title{
HÄRKÄPAPU LYPSYLEHMIEN VALKUAISREHUNA
}

\author{
Laura Puhakka, Seija Jaakkola, Tuomo Kokkonen, Aila Vanhatalo \\ Helsingin yliopisto, Maataloustieteiden laitos, PL 28 (Koetilantie 5), 00014 Helsingin yliopisto \\ etunimi.sukunimi@helsinki.fi
}

\section{TIIVISTELMÄ}

Suomen valkuaisomavaraisuutta voidaan parantaa lisäämällä palkoviljojen viljelyä ja käyttämällä niitä tuotantoeläinten rehuksi. Härkäpapu on potentiaalinen valkuaisrehu, mutta tutkimustuloksia härkäpavun käytöstä lypsylehmien ruokinnassa on julkaistu erittäin vähän. Tutkimustiedon tarve ja kiinnostus härkäpavun soveltuvuudesta erityisesti meille tyypilliseen nurmisäilörehuvaltaiseen ruokintaan on lisääntynyt huomattavasti. Tämän tutkimuksen tavoitteena oli selvittää härkäpavun tuotantovaikutusta ja ravintoaineiden hyväksikäyttöä lypsylehmien ruokinnassa. Härkäpapua tutkittiin kahdessa kokeessa Viikin opetus- ja tutkimustilan navetassa. Ensimmäisessä kokeessa oli kahdeksan 2 - 4 kertaa poikinutta ay-lehmää. Kokeen alkaessa poikimisesta oli kulunut keskimäärin 100 pv. Koemallina oli toistettu 4 x 4 latinalainen neliö. Isonitrogeenisissä väkirehuissa valkuaisen lähteenä oli rypsirouhe, härkäpapu tai näiden sekoitus (1:1) vastaten 3,5 kg:n rypsiannosta/pv. Kontrolliväkirehuun ei lisätty valkuaista. Väkirehuannos oli $14 \mathrm{~kg} / \mathrm{pv}$. Koejaksoja oli neljä ja yhden jakson pituus oli 21 päivää. Toisessa ruokintakokeessa oli mukana 12 ay-lehmää, joiden poikimisesta oli kulunut keskimäärin 111 pv kokeen alussa. Syklisessä jaksokokeessa oli kuusi väkirehuruokintaa, kaksi 6 eläimen blokkia (ensikot ja vähintään 2 kertaa poikineet) ja kolme 21 vuorokauden jaksoa. Valkuaislähteenä väkirehuissa oli rypsirouhe, härkäpapu tai niiden sekoitus (1:1) joko matalalla tai korkealla valkuaistasolla vastaten vanhemmilla lehmillä 1,5 ja 3,5 kg rypsiä/pv. Lehmät saivat väkirehua keskimäärin $11 \mathrm{~kg} / \mathrm{pv}$. Molemmissa kokeissa lehmät saivat hyvälaatuista nurmisäilörehua vapaasti. Ensimmäisessä kokeessa valkuaisruokinnat lisäsivät säilörehun syöntiä ja maitotuotosta $(+1,6-5,1 \mathrm{~kg} / \mathrm{pv})$ kontrolliin verrattuna. Odotusten vastaisesti härkäpapuruokinta lisäsi syöntiä ja maitotuotosta enemmän kuin rypsiruokinta. Maitotuotos sekä valkuais-, rasva- ja laktoosituotokset olivat kuitenkin suuremmat, kun puolet rypsirouheesta korvattiin härkäpavulla verrattuna rypsirouheen täydelliseen korvaamiseen härkäpavulla. Tutkimuksen toisessa kokeessa rypsiruokinta lisäsi syöntiä ja maitotuotosta (keskimäärin $+2,2 \mathrm{~kg} / \mathrm{pv}$ ) enemmän kuin härkäpapuruokinta. Syönti lisääntyi korkeamman valkuaistason rypsiruokinnoilla mutta väheni härkäpapuruokinnoilla. Maidon valkuaispitoisuus sekä valkuais-, rasva- ja laktoosituotokset olivat suuremmat rypsiruokinnalla verrattuna härkäpapuruokintaan. Valkuaistason nosto lisäsi maidon ureapitoisuutta kaikilla ruokinnoilla ja ureapitoisuus lisääntyi myös härkäpapuruokinnalla verrattuna rypsiruokintaan. Ruokintakokeiden perusteella härkäpapu lisää maitotuotosta verrattuna väkirehuruokintaan, jossa ei ole valkuaista mutta maitotuotos ei yllä rypsistä saatavan tuotosvasteen tasolle.

Asiasanat: härkäpapu, lypsylehmä, maitotuotos, nurmisäilörehu, rypsirouhe, syönti, valkuaisrehu 


\section{JOHDANTO}

Suomen kotieläintalouden riippuvuutta ulkomaisista valkuaisrehuista voidaan vähentää lisäämällä palkoviljojen viljelyä ja käyttämällä niitä kotieläinten rehuksi. Härkäpavun käyttö tilan viljelykierrossa ja eläinten ruokinnassa vähentää lannoite- ja ostorehukustannuksia. Härkäpapu on potentiaalinen valkuaisrehu, mutta tutkimustuloksia härkäpavun käytöstä lypsylehmien ruokinnassa on julkaistu erittäin vähän. Tutkimustiedon tarve ja kiinnostus härkäpavun soveltuvuudesta erityisesti meille tyypilliseen nurmisäilörehuvaltaiseen ruokintaan on lisääntynyt huomattavasti viime vuosina.

Härkäpapulajikkeiden siementen valkuaispitoisuus vaihtelee $270-320 \mathrm{~g} / \mathrm{kg}$ ka välillä (Crépon ym. 2010). Härkäpavun siemenissä tärkkelys on pääasiallinen energian lähde ja sen pitoisuus on keskimäärin $423 \mathrm{~g} / \mathrm{kg} \mathrm{ka} \mathrm{(Duc} \mathrm{ym.} \mathrm{1999).} \mathrm{Tärkkelyspitoisuudella} \mathrm{on} \mathrm{negatiivinen} \mathrm{korrelaatio} \mathrm{valkuaispi-}$ toisuuden kanssa (Duc ym. 1999). Härkäpavun siemenet sisältävät verrattain vähän rikkipitoisia aminohappoja. Viljoihin verrattuna härkäpavun siementen lysiinipitoisuus on suuri, mutta metioniini-, kysteiini- ja tryptofaanipitoisuus pieni (Duc ym. 1999). Maidontuotantoa rajoittavista aminohapoista (Vanhatalo ym. 1999) härkäpapu sisältää histidiiniä lähes yhtä paljon kuin rypsi, mutta metioniinia vähemmän.

Härkäpavun valkuainen hajoaa pötsissä nopeasti ja sen pötsihajoavuus on suuri nailonpussimenetelmällä mitattuna (Yu ym. 1998). Valkuaisen ja tärkkelyksen hajoavuuteen voidaan vaikuttaa erilaisilla käsittelyillä, kuten ekstruusiolla (Cros ym. 1991). Härkäpavun tärkkelys hajoaa sekä pötsissä että ohutsuolessa vähemmän kuin ohran ja vehnän tärkkelys (Larsen ym. 2009).

Härkäpavun maidontuotantovaikutuksesta ja ravintoaineiden hyväksikäytöstä on vain vähän tutkimustietoa saatavilla. Katsausartikkelissaan Crépon ym. (2010) esittivät tutkimustuloksia ranskalaisista tutkimuksista, joissa härkäpapua verrattiin soijaan lypsylehmien väkirehuruokinnassa maissisäilörehun ollessa karkearehuna. Kun härkäpavulla korvattiin $30 \%$ soijasta, syönti, maitotuotos ja maidon koostumus pysyivät ennallaan. Volpelli ym. (2010 ja 2012) tutkivat härkäpavun tuotantovaikutusta kahdessa lypsylehmäkokeessa, joissa pyrittiin löytämään gmo-vapaa valkuaisrehu parmesaanijuustomaidon tuotantoa varten. Ensimmäisessä kokeessa korvattiin $10 \%$ soijasta härkäpavulla ja toisessa kokeessa soijasta korvattiin $10 \%$ härkäpavulla ja $15 \%$ herneellä. Kummassakaan kokeessa ei soijan korvaamisella ollut negatiivista vaikutusta lehmien rehun syöntiin tai maitotuotokseen. Vastaavia ruokintakokeita, joissa härkäpavulla olisi korvattu rypsirouhetta, ei ole tiedossa. Tämän tutkimuksen tavoitteena oli selvittää härkäpavun tuotantovaikutusta ja ravintoaineiden hyväksikäyttöä lypsylehmien säilörehupohjaisessa ruokinnassa rypsiin verrattuna.

\section{AINEISTO JA MENETELMÄT}

Härkäpapua tutkittiin kahdessa lypsylehmäkokeessa Viikin opetus- ja tutkimustilan navetassa. Molemmissa kokeissa lehmät saivat 1 . sadon timotei-nurminatasäilörehua vapaasti. Koe 1. oli fysiologinen ruokintakoe, jossa oli mukana kahdeksan vähintään kaksi kertaa poikinutta ay-lehmää. Kokeen alkaessa lehmien poikimisesta oli kulunut keskimäärin 100 päivää. Koemallina oli toistettu 4x4 latinalainen neliö. Kokeessa oli neljä 21 vrk:n jaksoa, neljä koekäsittelyä ja kaksi neljän lehmän blokkia. Ensimmäisen blokin lehmillä oli pötsifistelit. Isonitrogeenisissä (raakavalkuaista, RV, 199 g/kg ka) ja pelletöidyissä koerehuissa oli valkuaisen lähteenä rypsirouhe, härkäpapu tai näiden sekoitus (1:1). Korvattavana perusväkirehuna ja kontrollina toimi viljapohjainen väkirehuseos (ohra, vehnä, kaura, melassileike, seosmelassi, rankki ja rehujauholeseseos), johon ei lisätty valkuaistäydennystä (RV 147 $\mathrm{g} / \mathrm{kg} \mathrm{ka)}$. Vuorokauden väkirehuannos oli $14 \mathrm{~kg}$. Tutkittavat valkuaisrehukäsittelyt vastasivat $3,5 \mathrm{~kg}: \mathrm{n}$ rypsi- ja vastaavasti 4,2 kg:n härkäpapuannosta.

Tutkimuksen toisessa ruokintakokeessa (koe 2.) oli mukana 12 ay-lehmää, joista puolet oli ensikoita ja puolet vanhempia lehmiä. Poikimisesta oli kulunut keskimäärin 111 päivää kokeen alkaessa. Syklisessä jaksokokeessa oli kuusi väkirehuruokintaa, kaksi 6 eläimen blokkia ja kolme 21 vrk:n jaksoa. Koe oli 3 x 2 faktoriaalinen siten, että pelletöityjen väkirehujen valkuaislähteenä oli rypsirouhe, härkäpapu tai näiden sekoitus (1:1) ja rehuissa oli joko matala (RV $170 \mathrm{~g} / \mathrm{kg}$ ka) tai korkea (RV 210 $\mathrm{g} / \mathrm{kg} \mathrm{ka)}$ valkuaistaso. Matala valkuaistaso vastasi keskimäärin 1,4 kg rypsiä/pv ja 1,7 kg härkäpapua päivässä ja korkea valkuaistaso 3,2 kg rypsiä ja 3,9 kg härkäpapua. Lehmät saivat tutkittavia väkirehu- 
ja keskimäärin $11 \mathrm{~kg} / \mathrm{pv}$, ja ne koostuivat valkuaistäydennyksen lisäksi melassileikkeestä, ohrasta, kaurasta, vehnästä ja seosmelassista.

Molemmissa kokeissa lehmiltä mitattiin syönti, maitotuotos ja maidon koostumus. Ensimmäisessä kokeessa pötsifistelöidyillä lehmillä tehtiin sonnan ja virtsan kokonaiskeruu ravintoaineiden kokonaissulavuuden selvittämiseksi ja lisäksi pötsistä otetuista näytteistä mitattiin $\mathrm{pH}$, haihtuvien rasvahappojen (VFA) ja ammoniakin pitoisuudet. Verinäytteet otettiin häntäsuonesta yhden päivän aikana kolmesti ja näytteenottoaikojen yli yhdistetyistä plasmoista määritettiin glukoosi, NEFA, BHBA ja aminohapot. Tulokset laskettiin koejaksojen viimeisen viikon tietojen perusteella. Tilastollinen analyysi tehtiin SAS:n Mixed -ohjelmistoa käyttäen. Ensimmäisestä kokeesta jäi puuttumaan yhden lehmän havainnot kahdelta jaksolta sairastumisen vuoksi. Koekäsittelyiden väliset erot testattiin ortogonaalisten kontrastien avulla. Ensimmäisessä kokeessa kontrastit olivat: 1. kontrolli vs. valkuaisruokinnat, 2. rypsi vs. härkäpapu ja 3. rypsin ja härkäpavun yhdysvaikutus. Toisen kokeen kontrastit olivat: 1. valkuaistason vaikutus (matala valkuaistaso vs. korkea valkuaistaso), 2 . valkuaisen lähteen vaikutus (rypsi vs. härkäpapu), 3. rypsin ja härkäpavun yhdysvaikutus, 4. yhdysvaikutus 1 x 2 (valkuaistaso x valkuaislähde) ja 5. yhdysvaikutus 1 x 3 (valkuaistaso x valkuaislähteiden yhdysvaikutus).

\section{TULOKSET JA TULOSTEN TARKASTELU}

Molempien kokeiden koerehujen koostumus on esitetty taulukossa 1. Kokeissa käytetyt säilörehut olivat säilönnällisesti ja sulavuudeltaan hyvälaatuisia. Ensimmäisessä kokeessa lehmien kuiva-aineen syönti ja maitotuotos lisääntyivät valkuaisruokinnoilla keskimäärin 2,5 ja 3,5 kg verrattuna kontrolliruokintaan (taulukko 2). Vastoin odotuksia rypsitäydennyksellä ei saatu yhtä suurta säilörehun syönnin ja maitotuotoksen lisäystä kuin aikaisemmissa tutkimuksissa (Huhtanen 1998, Huhtanen ym. 2011). Sen sijaan rypsirouheen korvaaminen härkäpavulla valkuaisruokinnassa lisäsi lehmien säilörehun ja kokonaiskuiva-aineen syöntiä ja maitotuotosta merkitsevästi. Maitotuotosvasteet energiakorjattu maitotuotos mukaan lukien olivat kuitenkin merkitsevästi suurempia valkuaislisän koostuessa rypsin ja härkäpavun 1:1 seoksesta kuin sen koostuessa pelkästään joko härkäpavusta tai rypsistä. Käytettäessä rypsin ja härkäpavun seosta lehmät tuottivat $1,5 \mathrm{~kg} / \mathrm{pv}$ enemmän energiakorjattua maitoa kuin käytettäessä härkäpapua vaikka näiden ruokintojen kokonaiskuiva-aineen syönneissä ei ollut eroa. Rypsin ja härkäpavun positiivinen yhdysvaikutus näkyi myös merkitsevästi suurempina valkuais- rasva ja laktoosituotoksina härkäpapuruokintaan verrattuna. Valkuaistäydennettyjen ruokintojen sulavuuksissa, pötsikäymisessä tai plasman muissa parametreissa ei ollut kuitenkaan eroa ruokintojen välillä.

Johtuen suuremmasta kuiva-aineen syönnistä ja siten parantuneesta energian saannista maidon valkuaispitoisuus suureni korvattaessa rypsiä härkäpavulla. Maidon rasvapitoisuudessa ei ollut eroa valkuaisruokintojen välillä, mutta valkuaislisä ruokinnassa pienensi rasvapitoisuutta kontrolliin verrattuna. Tämä oli yhteydessä pötsikäymiseen, jossa voihapon osuus haihtuvista rasvahapoista oli valkuaisruokinnoilla kontrollia pienempi. Kontrolliruokinnan lehmien suurempi veren NEFA-pitoisuus voi myös selittää kohonnutta maidon rasvapitoisuutta, koska veren vapaiden rasvahappojen pitoisuuden noustessa niiden käyttö maitorasvan synteesiin lisääntyy (Bauman ja Griinari 2001). Pötsin pH oli tässä kokeessa keskimäärin kuuden tuntumassa. Valkuaisruokintojen $\mathrm{pH}$ oli kuitenkin numeerisesti kontrollia suurempi, mikä johtunee valkuaisen happamuutta neutraloivasta vaikutuksesta. Lisäksi valkuaisruokintojen $\mathrm{pH}$ minimissään oli merkitsevästi suurempi kuin kontrollin $(5,67$ vs. 5,38$)$ viitaten siihen, että kontrolliruokinnalla säilörehun syönti oli saattanut alentua tästä syystä.

Tutkimuksen toisessa kokeessa lehmien kuiva-aineen syönti sekä maitotuotos olivat molemmilla valkuaistasoilla suurempia rypsiruokinnalla verrattuna härkäpapuruokintaan (taulukko 3). Valkuaistason nosto lisäsi lehmien rehun syöntiä ruokinnoilla, joissa valkuaislähteenä oli rypsi tai rypsin ja härkäpavun 1:1 seos. Härkäpapuruokinnalla lehmien rehun syönti väheni, kun valkuaistasoa nostettiin. Maidon valkuais- ja laktoosituotokset olivat niin ikään suuremmat rypsiruokinnoilla kuin härkäpapuruokinnoilla. Rasvatuotoksessa oli samansuuntainen, mutta vain suuntaa-antava ero. Maidon valkuaispitoisuus oli rypsiruokinnoilla suurempi verrattuna härkäpapuruokintoihin, mutta maidon rasva- tai laktoosipitoisuuksissa ei ollut tilastollisesti merkitseviä eroja. Maidon ureapitoisuus lisääntyi kun valkuaistasoa nostettiin. Molemmilla valkuaistasoilla maidon ureapitoisuus oli suurempi härkäpapuruokinnoilla verrattuna rypsiruokintoihin, joka viittaa rypsistä saadun valkuaisen parempaan hyväksikäyttöön. 
Kotimaisissa tutkimuksissa on todettu rypsin sopivan lypsylehmien nurmisäilörehupohjaiseen ruokintaan erinomaisesti. Korvattaessa viljapohjaista väkirehua rypsillä on yhden rypsikilon lisäys ruokintaan lisännyt maitotuotosta vastaavasti yhdellä kilolla (Huhtanen 1998). Tutkimuksen ensimmäisessä kokeessa rypsikilolla saatu maitotuotosvaste jäi vain noin puoleen edellä mainitusta. Härkäpapuruokinnoilla sen sijaan yhden härkäpapukilon lisäys ruokintaan lisäsi maitotuotosta lähes kilolla. Rypsin härkäpapua heikompi vaste johtui lehmien pienemmästä kuiva-aineen syönnistä ja siten pienemmästä energian saannista, mutta mitään ilmeistä syytä alentuneeseen syöntiin ei ole tiedossa. Rypsirehun glukosinolaattipitoisuus oli alle viitearvojen, joten todennäköisesti syönti ei vähentynyt ainakaan haitta-aineiden takia. Tutkimuksen toisessa kokeessa yhden rypsikilon lisääminen ruokintaan lisäsi maitotuotosta keskimäärin vain $0,65 \mathrm{~kg}$, kun annosta lisättiin 1,4 kilosta 3,2 kiloon. Kun härkäpavun määrää nostettiin ensikoilla 1,5 kg:sta 3,5 kg:aan ja vanhemmilla lehmillä 1,8 kg:sta 4,2 kg:aan, ei härkäpavun suuremmasta määrästä saatu vastaavaa hyötyä, vaan maitotuotos väheni numeerisesti keskimäärin $0,3 \mathrm{~kg}$. Tässäkään kokeessa rypsilisäys ei siten tuottanut Huhtasen (1998) toteamaa maitotuotoksen lisääntymistä täysimääräisesti. Syynä saattaa olla kokeissa käytössä ollut hyvälaatuinen säilörehu, josta lehmät saivat runsaasti mikrobivalkuaista ja siten rypsilisäyksen maitotuotosvaikutus jäi vain kohtuulliseksi. Härkäpapuruokinnoilla lehmien aminohappojen saanti kudostasolla jäi todennäköisesti vähäisemmäksi verrattuna rypsiruokintoihin ja siten saattoi rajoittaa maidontuotantoa. Tähän viittaa sekin, että ensimmäisessä kokeessa paras tuotosvaste saatiin käytettäessä rypsin ja härkäpavun 1:1 seosta, joka johti positiiviseen yhteisvaikutukseen maidontuotannossa.

\section{JOHTOPÄÄTÖKSET}

Tutkimuksen ensimmäisessä kokeessa härkäpapukilon lisäys ruokintaan lisäsi maitotuotosta lähes kilolla. Odotusten vastaisesti kokeessa rypsiruokinnalla olleet lehmät söivät vähemmän ja siten maitotuotosvaste oli härkäpapua pienempi. Tutkimuksen toisessa kokeessa lehmien maitotuotos jäi pienemmäksi härkäpapuruokinnalla verrattuna rypsiruokintaan. Valkuaistason nostolla ei ollut vaikutusta maitotuotokseen. Tämän tutkimuksen perusteella härkäpapu lisää lypsylehmien maitotuotosta viljapohjaiseen väkirehuruokintaan verrattuna ja härkäpavulla voidaan korvata osa rypsistä vaikuttamatta maitotuotokseen negatiivisesti.

\section{KIRJALLISUUS}

Bauman, D. \& Griinari M. Regulation and nutritional manipulation of milk fat: low-fat milk syndrome. Livestock Production Science 70:15-29.

Crépon, K., Marget, P., Peyronnet, C., Carrouée, B., Arese, P. \& Duc, G. 2010. Nutritional value of faba bean (Vicia faba L.) seeds for feed and food. Field Crops Research 115:329-339.

Cros, P., Vernay, M. \& Moncoulon, R. 1991. In situ evaluation of the ruminal and intestinal degradability of extruded whole horsebeans. Reproduction Nutrition Development 31:249-255.

Duc, G., Marget, P., Esnault, R., Le Guen, J. \& Bastianelli, D. 1999. Genetic variability for feeding value of faba bean seeds (Vicia faba) : Comparative chemical composition of isogenics involving zero-tannin and zerovicine genes. Journal of Agricultural Science 133:185-196.

Faurie, F., Schametz, C. \& Tisserand, J.L. 1992. Nitrogen Content Degradability of Any Proteaginous Seeds. Lère Conférence Européenne sur les Protéagineux. Angers. AEP, ss. 515-516.

Huhtanen, P. 1998. Supply of nutrients and productive responses in dairy cows given diets based on restrictively fermented grass silage. Agricultural and Food Science in Finland 7: 219-250.

Huhtanen, P., Hetta, P., \& Swensson, C. 2011. Evaluation of canola meal as a protein supplement for dairy cows: A review and a meta-analysis. Canadian Journal of Animal Science 91: 529-543.

Larsen, M., Lund, P., Weisbjerg, M. R. \& Hvelplund, T. 2009. Digestion site of starch from cereals and legumes in lactating dairy cows. Animal Feed Science and Technology 153:236-248.

Sjaunja, L. O., Baevre, L., Junkarinen, L., Pedersen, J. \& Setälä, J. 1990. A Nordic proposal for an energy corrected milk (ECM) formula. Proc. $27^{\text {th }}$ Biennial session Int. Committee for Animal Recording. ICAR, Pariisi, Ranska. ss. 156-157.

Vanhatalo, A., Huhtanen, P., Toivonen, V. \& Varvikko, T. 1999. Response of dairy cows fed grass silage diets to abomasal infusions of histidine alone or in combinations with methionine and lysine. Journal of dairy Science 82:2674-2685.

Volpelli, L., Comellini, M., Gozzi, M., Masoero, F. \& Moschini, M. 2012. Pea (Pisum sativum) and faba beans (Vicia faba) in dairy cow diet: effect on milk production and quality. Italian Journal of Animal Science 11:e40. 
Volpelli, L., Comellini, M., Masoero, F., Moschini, M., Lo Fiego, D. \& Scipioni, R. 2010. Faba beans (Vicia faba) in dairy cow diet: effect on milk production and quality. Italian Journal of Animal Science 9:e27.

Yu, P., Holmes, J. H. G., Leury, B. J. \& Egan, A. R. 1998. Influence of dry roasting on rumen protein degradation chracteristics of whole faba bean (Vicia faba) in dairy cows. Asian-Australasian Journal of Animal Sciences 11(1):35-42.

Taulukko 1. Koerehujen koostumus.

\begin{tabular}{|c|c|c|c|c|c|c|c|}
\hline \multirow[b]{2}{*}{ KOE 1.} & \multirow[b]{2}{*}{ Säilörehu $^{1}$} & \multicolumn{6}{|c|}{ Väkirehut } \\
\hline & & \multicolumn{2}{|l|}{ Kontrolli } & Rypsi & Rypsi/Hp ${ }^{3}$ & \multicolumn{2}{|c|}{ Härkäpapu } \\
\hline Kuiva-aine, g/kg & 276 & \multirow[t]{2}{*}{875} & \multirow{2}{*}{\multicolumn{2}{|c|}{873}} & 870 & \multirow{2}{*}{\multicolumn{2}{|c|}{866}} \\
\hline $\mathrm{pH}$ & 3,91 & & & & & & \\
\hline \multicolumn{8}{|c|}{ Kuiva-aineessa, g/kg } \\
\hline Tuhka & 79,7 & 54,4 & \multicolumn{2}{|c|}{64,6} & 63,9 & \multicolumn{2}{|c|}{63,0} \\
\hline Raakavalkuainen & 175 & 147 & \multicolumn{2}{|c|}{202} & 199 & \multicolumn{2}{|c|}{196} \\
\hline $\mathrm{NDF}^{4}$ & 520 & 215 & \multicolumn{2}{|c|}{221} & 195 & \multicolumn{2}{|c|}{169} \\
\hline Tärkkelys & & 374 & \multicolumn{2}{|c|}{294} & 315 & \multicolumn{2}{|c|}{334} \\
\hline D-arvo & 709 & & & & & & \\
\hline $\mathrm{ME} \mathrm{MJ/kg} \mathrm{ka}$ & 11,3 & 12,5 & \multicolumn{2}{|c|}{12,3} & 12,4 & \multicolumn{2}{|c|}{12,6} \\
\hline OIV & 89 & 99 & \multicolumn{2}{|c|}{114} & 112 & \multicolumn{2}{|c|}{110} \\
\hline \multirow[t]{2}{*}{ PVT } & 44,8 & $-8,5$ & & & 36,3 & & \\
\hline & & \multicolumn{3}{|c|}{ Matala valkuaistaso } & \multicolumn{3}{|c|}{ Korkea valkuaistaso } \\
\hline KOE 2. & Säilörehu ${ }^{2}$ & Rypsi & Rypsi/Hp & $\mathrm{Hp}$ & Rypsi & Rypsi/Hp & $\mathrm{Hp}$ \\
\hline Kuiva-aine, g/kg & 215 & 874 & 874 & 874 & 875 & 874 & 873 \\
\hline $\mathrm{pH}$ & 3,79 & & & & & & \\
\hline \multicolumn{8}{|c|}{ Kuiva-aineessa, g/kg } \\
\hline Tuhka & 69,1 & 63,3 & 61,4 & 59,5 & 67,0 & 62,6 & 58,2 \\
\hline Raakavalkuainen & 171 & 154 & 154 & 154 & 191 & 190 & 189 \\
\hline $\mathrm{NDF}$ & 529 & 219 & 211 & 203 & 222 & 203 & 184 \\
\hline Tärkkelys & & 311 & 334 & 352 & 268 & 315 & 357 \\
\hline D-arvo & 716 & & & & & & \\
\hline $\mathrm{ME} \mathrm{MJ/kg} \mathrm{ka}$ & 11,46 & 12,5 & 12,6 & 12,6 & 12,3 & 12,4 & 12,6 \\
\hline OIV & 88 & 106 & 105 & 105 & 119 & 117 & 115 \\
\hline PVT & 40,2 & 1,8 & 1,3 & 0,9 & 33,1 & 31,9 & 30,6 \\
\hline
\end{tabular}

${ }^{\mathrm{T}} \mathrm{NH}_{3}-\mathrm{N} 56 \mathrm{~g} / \mathrm{kg} \mathrm{N}$, sokerit $48 \mathrm{~g} / \mathrm{kg}$ ka, maitohappo $62 \mathrm{~g} / \mathrm{kg}$ ka, etikkahappo $12 \mathrm{~g} / \mathrm{kg} \mathrm{ka}$, voihappo $1 \mathrm{~g} / \mathrm{kg} \mathrm{ka}$, syönti-indeksi 108

${ }^{2} \mathrm{NH}_{3}-\mathrm{N} 47 \mathrm{~g} / \mathrm{kg} \mathrm{N}$, sokerit $62 \mathrm{~g} / \mathrm{kg} \mathrm{ka}$, maitohappo $59 \mathrm{~g} / \mathrm{kg} \mathrm{ka}$, etikkahappo $18 \mathrm{~g} / \mathrm{kg}$ ka, voihappo 0,5 g/kg ka, syönti-indeksi 105

${ }^{3}$ Rypsin ja härkäpavun seos $(1: 1),{ }^{4}$ neutraalidetergenttikuitu 
Taulukko 2. Syönti, ravintoaineiden saanti, rehuannoksen sulavuus ja maitotuotos. Koe 1 .

\begin{tabular}{|c|c|c|c|c|c|c|c|c|}
\hline & \multicolumn{4}{|c|}{ Ruokinnat } & \multirow[b]{2}{*}{ SEM } & \multicolumn{3}{|c|}{ Kontrastit $^{1}$} \\
\hline & Kontrolli & Rypsi & Rypsi/Hp & $\mathrm{Hp}^{2}$ & & 1 & 2 & 3 \\
\hline \multicolumn{9}{|c|}{ Syönti ja ravintoaineiden saanti } \\
\hline Säilörehu, kg ka/pv & 7,3 & 8,1 & 10,2 & 10,7 & 0,77 & $* *$ & $* *$ & \\
\hline Väkirehu, kg ka/pv & 11,9 & 11,8 & 12,2 & 12,1 & 0,21 & & & \\
\hline Yhteensä, kg ka/pv & 19,2 & 19,8 & 22,4 & 22,8 & 0,84 & $* *$ & $* *$ & \\
\hline Orgaaninen aine, $\mathrm{kg} / \mathrm{pv}$ & 18,0 & 18,4 & 20,8 & 21,1 & 0,78 & $* *$ & $* *$ & \\
\hline Raakavalk., kg/pv & 3,03 & 3,79 & 4,21 & 4,24 & 0,14 & $* * *$ & $* *$ & \\
\hline $\mathrm{NDF}^{3}, \mathrm{~kg} / \mathrm{pv}$ & 6,35 & 6,79 & 7,68 & 7,60 & 0,42 & $* *$ & o & \\
\hline Tärkkelys, kg/pv & 4,45 & 3,46 & 3,83 & 4,02 & 0,09 & $* * *$ & $* * *$ & \\
\hline $\mathrm{ME} \mathrm{MJ/pv}$ & 234 & 238 & 271 & 275 & 10,3 & $* *$ & $* *$ & \\
\hline \multicolumn{9}{|l|}{ Sulavuus } \\
\hline Orgaaninen aine & 0,768 & 0,766 & 0,767 & 0,759 & 0,0071 & & & \\
\hline Raakavalkuainen & 0,708 & 0,733 & 0,731 & 0,710 & 0,0100 & & $*$ & \\
\hline $\mathrm{NDF}$ & 0,624 & 0,610 & 0,634 & 0,632 & 0,0300 & & & \\
\hline Tärkkelys & 0,971 & 0,963 & 0,963 & 0,960 & 0,0025 & & $*$ & \\
\hline \multicolumn{9}{|c|}{ Tuotokset ja hyväksikäyttö } \\
\hline Maito, kg/pv & 28,2 & 29,8 & 33,1 & 32,3 & 1,81 & $* * *$ & $*$ & $*$ \\
\hline $\mathrm{EKM}^{4}, \mathrm{~kg} / \mathrm{pv}$ & 29,7 & 30,3 & 34,5 & 33,0 & 1,92 & $*$ & o & * \\
\hline Rasva, g/pv & 1261 & 1229 & 1414 & 1324 & 95,3 & & & $*$ \\
\hline Valkuainen, g/pv & 952 & 1022 & 1178 & 1158 & 49,8 & $* * *$ & $* *$ & $*$ \\
\hline Laktoosi, g/pv & 1289 & 1370 & 1509 & 1472 & 86,7 & $* *$ & o & $\mathrm{O}$ \\
\hline EKM, kg/kg ka & 1,55 & 1,52 & 1,50 & 1,41 & 0,050 & $* *$ & $* * *$ & \\
\hline Maito N/Rehu N & 0,31 & 0,26 & 0,27 & 0,26 & 0,004 & $* * *$ & & \\
\hline \multicolumn{9}{|l|}{ Koostumus } \\
\hline Rasva, g/kg & 44,7 & 41,0 & 42,5 & 41,1 & 1,63 & $*$ & & \\
\hline Valkuainen, g/kg & 34,0 & 34,4 & 35,9 & 36,1 & 1,23 & $*$ & $*$ & \\
\hline Laktoosi, g/kg & 45,6 & 45,8 & 45,5 & 45,5 & 0,27 & & & \\
\hline Urea, mg/dl & 29,4 & 40,5 & 36,8 & 34,2 & 2,15 & $* * *$ & $* *$ & \\
\hline \multicolumn{9}{|c|}{ Plasman parametrit, $\mu \mathrm{mol} / \mathrm{l}$} \\
\hline Glukoosi & 4,03 & 4,05 & 3,93 & 3,90 & 0,127 & & & \\
\hline $\mathrm{NEFA}^{5}$ & 240 & 175 & 119 & 93,5 & 45,18 & * & & \\
\hline $\mathrm{BHBA}^{6}$ & 1,41 & 1,04 & 1,12 & 0,88 & 0,231 & $*$ & & \\
\hline $\mathrm{EAA}^{7}$ & 890 & 986 & 966 & 1002 & 50,0 & $* * *$ & & \\
\hline TAA $^{8}$ & 2305 & 2361 & 2458 & 2503 & 78,0 & $* *$ & $*$ & \\
\hline \multicolumn{9}{|l|}{ Pötsifermentaatio } \\
\hline $\mathrm{pH}$ & 5,87 & 6,00 & 5,97 & 6,01 & 0,057 & & & \\
\hline Alkueläimet, kpl x $10^{5}$ & 11,4 & 10,1 & 11,0 & 10,2 & 2,889 & & & \\
\hline Ammonium-N, mmol/l & 7,43 & 11,6 & 11,9 & 11,9 & 1,526 & $* * *$ & & \\
\hline VFA yht., mmol/1 & 124 & 125 & 122 & 120 & 5,1 & & & \\
\hline Etikkah., $\mathrm{mmol} / \mathrm{mol}$ & 633 & 619 & 634 & 628 & 9,0 & & & \\
\hline Propionih., mmol/mol & 164 & 198 & 179 & 182 & 12,0 & & & \\
\hline Voihappo, mmol/mol & 161 & 135 & 147 & 147 & 5,1 & $*$ & & \\
\hline
\end{tabular}

${ }^{\mathrm{T}} 1$ = Kontrolli vs. muut, 2 = Rypsi vs. härkäpapu, 3 = Rypsin ja härkäpavun yhdysvaikutus, ${ }^{2}$ Härkäpapu,

${ }^{3}$ Neutraalidetergenttikuitu, ${ }^{4}$ Energiakorjattu maitotuotos (Sjaunja ym. 1990), ${ }^{5}$ Vapaat rasvahapot,

${ }^{6}$ Betahydroksivoihappo, ${ }^{7}$ Välttämättömät aminohapot (Arg, His, Ile, Leu,Lys,Met,Phe,Thr,Trp ja Val), Välttämättömät ja ei-välttämättömät aminohapot yhteensä

$* * * \mathrm{P}<0,001, * * \mathrm{P}<0,01, * \mathrm{P}<0,05, \mathrm{oP}<0,10$ 
Taulukko 3. Syönti, ravintoaineiden saanti, rehuannoksen sulavuus ja maitotuotos. Koe 2.

\begin{tabular}{|c|c|c|c|c|c|c|c|c|c|c|c|c|}
\hline & \multicolumn{3}{|c|}{ Matala valkuaistaso } & \multicolumn{3}{|c|}{ Korkea valkuaistaso } & \multirow[b]{2}{*}{ SEM } & \multicolumn{5}{|c|}{ Kontrastit $^{1}$} \\
\hline & Rypsi & $\mathrm{R} / \mathrm{Hp}^{2}$ & $\mathrm{Hp}$ & Rypsi & $\mathrm{R} / \mathrm{Hp}$ & $\mathrm{Hp}$ & & 1 & 2 & 3 & 4 & 5 \\
\hline \multicolumn{13}{|c|}{ Syönti ja ravintoaineiden saanti } \\
\hline Säilörehu, kg ka/pv & 10,3 & 10,1 & 9,5 & 10,9 & 10,0 & 8,7 & 0,35 & & $* * *$ & & $* *$ & \\
\hline Väkirehu, kg ka/pv & 9,9 & 9,9 & 9,9 & 9,9 & 9,9 & 9,9 & 0,39 & & & & & \\
\hline Yhteensä, kg ka/pv & 20,4 & 20,2 & 19,7 & 20,9 & 20,9 & 18,1 & 0,55 & & $* *$ & & o & \\
\hline Orgaaninen aine, $\mathrm{kg} / \mathrm{pv}$ & 18,9 & 18,7 & 18,2 & 19,4 & 18,7 & 17,4 & 0,33 & & $* * *$ & & $*$ & \\
\hline Raakavalkuainen, kg/pv & 3,30 & 3,26 & 3,16 & 3,75 & 3,59 & 3,36 & 0,06 & $* * *$ & $* * *$ & & $* *$ & \\
\hline $\mathrm{NDF}^{3}, \mathrm{~kg} / \mathrm{pv}$ & 7,76 & 7,54 & 7,13 & 8,08 & 7,42 & 6,55 & 0,19 & & $* * *$ & & $* *$ & \\
\hline Tärkkelys, kg/pv & 3,00 & 3,22 & 3,39 & 2,58 & 3,03 & 3,43 & 0,03 & $* * *$ & $* * *$ & & $* * *$ & \\
\hline $\mathrm{ME} \mathrm{MJ/pv}$ & 242 & 240 & 234 & 247 & 238 & 224 & 4,157 & & $* * *$ & & o & \\
\hline \multicolumn{13}{|c|}{ Tuotokset ja hyväksikäyttö } \\
\hline Maito, $\mathrm{kg} / \mathrm{pv}$ & 30,8 & 30,3 & 29,5 & 32,0 & 31,1 & 28,9 & 0,89 & & $* * *$ & & & \\
\hline $\mathrm{EKM}^{4}, \mathrm{~kg} / \mathrm{pv}$ & 31,3 & 30,8 & 29,9 & 31,9 & 31,3 & 29,4 & 1,03 & & $* * *$ & & & \\
\hline Valkuainen, g/pv & 1040 & 1002 & 965 & 1076 & 1019 & 933 & 33,4 & & $* * *$ & & o & \\
\hline Laktoosi, g/pv & 1413 & 1393 & 1352 & 1462 & 1423 & 1330 & 45,5 & & $* *$ & & & \\
\hline Rasva, g/pv & 1283 & 1275 & 1247 & 1286 & 1295 & 1230 & 53,7 & & o & & & \\
\hline EKM kg/kg ka & 1,55 & 1,54 & 1,54 & 1,53 & 1,57 & 1,57 & 0,040 & & & & & \\
\hline Maito N/Rehu N & 0,31 & 0,30 & 0,30 & 0,28 & 0,28 & 0,27 & 0,008 & $* * *$ & & & & \\
\hline \multicolumn{13}{|l|}{ Maidon koostumus } \\
\hline Valkuainen, g/kg & 33,9 & 32,9 & 32,7 & 33,7 & 32,8 & 32,2 & 0,66 & & $* * *$ & & & \\
\hline Laktoosi, g/kg & 45,9 & 46,0 & 45,8 & 45,6 & 45,8 & 46,0 & 0,40 & & & & & \\
\hline Rasva, g/kg & 41,9 & 42,0 & 42,3 & 40,3 & 41,6 & 42,3 & 1,29 & & & & & \\
\hline Urea, mg/dl & 29,0 & 29,2 & 30,3 & 31,9 & 36,3 & 38,9 & 1,65 & $* * *$ & $*$ & & o & \\
\hline \multicolumn{13}{|c|}{ Plasman aminohapot, $\mu \mathrm{mol} / \mathrm{l}$} \\
\hline BCAA $^{5}$ & 523 & 541 & 499 & 606 & 572 & 490 & 25,7 & o & $* *$ & & o & \\
\hline EAA $^{6}$ & 961 & 979 & 916 & 1081 & 1044 & 902 & 42,9 & o & $* *$ & & o & \\
\hline TAA $^{7}$ & 2347 & 2374 & 2326 & 2458 & 2409 & 2223 & 66,1 & 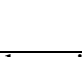 & $*$ & & $\mathrm{o}$ & \\
\hline
\end{tabular}

